\title{
How to increase engagement on social media using the honeycomb model
}

\section{A case study in a Portuguese HR company}

\author{
Susana C. Silva \\ Universidade Católica Portuguesa, Porto, Portugal \\ Wilian Feitosa \\ IFSP, Instituto Federal de Educacao Ciencia e Tecnologia de Sao Paulo, Sao Paulo, Brazil \\ Paulo Duarte \\ Departamento de Gestao e Economia, Universidade da Beira Interior, \\ Covilha, Portugal, and \\ Marta Vasconcelos \\ Universidade Católica Portuguesa, Porto, Portugal
}

\begin{abstract}
Purpose - The purpose of this paper is to understand how a company could improve public engagement on social media (SM) analysing the case of Alento, which is a human resources and consulting company located in Portugal. The company's presence on Facebook was analysed by using the honeycomb model for SM functionality, by Kietzmann et al. (2011), as a theoretical framework.

Design/methodology/approach - The authors implemented some actions to change procedures on SM management. Monitoring five months of data, the authors could compare the SM engagement before and after changes on SM management. Then, a convenience sample of 205 useable questionnaires was collected. The population of the study comprised Portuguese Facebook users who liked the Alento Facebook Fan Page. An analysis of honeycomb dimensions was performed.

Findings - The engagement level on Alento's SM was increased by changing procedures identified on survey. In five months, Alento's number of followers was increased by just 4.5 per cent, interactions were increased by 35 per cent, views were more than twice $(+122$ per cent) and fans who clicked on Alento's Facebook page's links were increased by 146 per cent.

Research limitations/implications - There were also some limitations related to the sample, since the authors only obtained 205 responses. Therefore, the second suggestion for future investigations would be to conduct the survey on a larger number of people. This study just considers five months after changing procedures. A longer range of time could produce different results.

Practical implications - The most relevant contribution of the current study is the offer of some insights into the use of a simple tool such as the honeycomb model of Kietzmann et al. (2011) for the analysis of the social engagement from a firm's perspective, regardless of their nature.

Social implications - The importance of SM to spread good content and to reduce media costs is reinforced in this study.

Originality/value - This study is innovative, as it identifies a need of change on SM management, proposes and implements new procedures, checking its results. SM marketing is a new wagon of study, and the problem of how to increase engagement on professional SM is on top priorities of the field.
\end{abstract}

Keywords Engagement, Digital marketing, Social media management

Paper type Technical paper

(C) Susana C. Silva, Wilian Feitosa, Paulo Duarte and Marta Vasconcelos. Published in Revista de Gestão. Published by Emerald Publishing Limited. This article is published under the Creative Commons Attribution (CC BY 4.0) licence. Anyone may reproduce, distribute, translate and create derivative works of this article (for both commercial and non-commercial purposes), subject to full attribution to the original publication and authors. The full terms of this licence may be seen at http://creativecommons.org/licences/by/4.0/legalcode

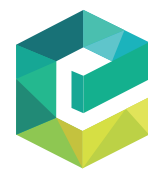

Revista de Gestão Vol. 27 No. 2, 2020 pp. 153-167 Emerald Publishing Limite e-ISSN: $2177-8736$ DOI 10.1108/REGE-02-2019-0030 
REGE

27,2

154

\section{Introduction}

Digitalisation has become a part of our daily life. As a result, digitalisation and particularly social media (SM) have been claimed to transform consumer behaviour (Kaplan \& Haenlein, 2010), with important consequences for companies, products and brands (Mutinga, Moorman, \& Smit, 2011). Nowadays, consumers spend much of their time on the internet. They are much more proactive in establishing channels with companies. However, companies use these channels more and more to promote their brands and to engage customers, especially by sharing informational brand content with links for information searches (Swani, Milne, Brown, Assaf, \& Donthu, 2017). Social networks are used by people of different ages, education levels, genders, social statuses, people who speak different languages and who come from different cultures, all of whom participate and incorporate social networks into their daily lives (Mazman \& Usluel, 2010). Previous studies have shown the differences between adolescents and older adults (over 60s) in the use of different SNS features and content (Pfeil, Arjan, \& Zaphiris, 2009). Muscanell and Guadagno (2012) found that young SNS users are much more active, have a larger number of Facebook friends, spend more time online and participate in the different activities available on Facebook. However, in comparison, older users prefer to engage in family activities on Facebook (Dhir \& Torsheim, 2016). Users can spend their time on Facebook, doing many different activities such as playing video games, joining groups, getting up-to-date information from friends and family or having fun (Sánchez, Cortijo, \& Javed, 2014). Previous literature has observed gender differences in SNS use. Gender differences were observed in the use of different SNS features, for example females tend to comment on friends' posts (Yuan, 2011) and they also post more photos and videos (Hargittai, 2007; Madden, Lenhart, \& Duggan, 2013; Muscanell \& Guadagno, 2012). In comparison, males tend to play games on SNS (Joiner et al., 2012; Muscanell \& Guadagno, 2012) and seek entertainment related to social networking activities (Joiner et al., 2012; Weiser, 2000). The profile differences are relevant, and this way it is important to understand well who the company's clients are, in order to better adapt the page contents to their preferences and chances of engagement. Although this is severely eroded (Mangold \& Faulds, 2009), marketing managers would still desire to control over the content, timing and frequency of information provided within the page. "In the new communications paradigm, marketing managers should recognize the power and critical nature of the discussions being carried on by consumers using social media" (Mangold \& Faulds, 2009, p. 360). Therefore, it is very important for firms to understand how to provide and organise the information they want their customers to consume through the SNS provided.

However, with the evolution of communication, it is gradually becoming more and more difficult to build customer loyalty (Buhalis \& Law, 2008), which means that having a marketing strategy for the effective use of SM is crucial for companies to stay competitive and grow (Parsons, 2013). Understanding SM users' habits is therefore crucial for marketers who need to discover how to attract customers and maintain customer relationships through SM platforms (Cheung \& Leung, 2016). According to Erragcha and Romdhane (2014), there is no global definition of Digital Social Networks. However, in marketing literature, the most suitable definition is that they are web services that "allow individuals to construct a public or semi-public profile within a system, to maintain a list of users with whom they share a bond, to view and navigate their list of connections and those established by others within the system” (Boyd \& Ellison, 2007, p. 2). Social networking sites allow for interaction between consumers and the community and facilitate the "asynchronous, immediate, interactive, lowcost communications" (Miller, Fabian, \& Lin, 2009). "Social network sites can be seen as alternative communication tools which support existing relationships and activities in a fun and colourful way that can enrich the users' experiences" (Ofcom, 2008).

This paper aims to investigate the applicability of SNS in a service company. Our goal is to understand how digital marketing strategies can be used in order to improve firm's digital 
marketing plan. We will focus on Facebook, as it is the largest social networking website in the world and, as a consequence, the most representative.

\section{Literature review}

Digital marketing, social media and customer engagement

Digital marketing can be seen as a tool to promote the company more efficiently, and it should be understood effectively by companies so that they are better able to select efficient marketing tactics and strategies (Taiminen \& Karjaluoto, 2015). Within digital marketing, we can isolate $\mathrm{SM}$ as "a group of internet-based applications that build on the ideological and technological foundations of Web 2.0 and that allow the creation and exchange of user generated content" (Kaplan \& Haenlein, 2010, p. 61). Social networking tools (e.g. Twitter and Facebook), professional networking sites (e.g. LinkedIn), media sharing sites (e.g. Instagram and YouTube), commerce communities (e.g. Amazon and eBay), blogs (e.g. Blogger and Bloglines) and discussion forums are examples of SM platforms. SM has changed the way companies have done business over the years (Ramsaran-Fowdar \& Fowdar, 2013), and as a result, in recent years, SM sites have become essential for users and companies (Maecker, Barrot, \& Becker, 2016). Although the internet has created huge new opportunities for companies over the years, it has also generated new challenges (Strand, 2011). However, there is a lack of understanding of how and why organisations are actually using these platforms (Tsimonis \& Dimitriadis, 2014).

$\mathrm{SM}$ is a way to generate companies and brands engagement in several actors and stakeholders, such as customers, suppliers and employees (Hollebeek et al., 2018). Customer engagement is a concept in evolution (Hollebeek, 2011) about how an actor can be profoundly interested and bounded in a company, in terms of trust, loyalty, commitment and confidence (Moriuchi, 2019), which include the B2B (Silva, Bradley, \& Sousa, 2012; Diba, Vella, \& Abratt, 2019 ) and the B2C contexts (Kesgin \& Murthy, 2019). Online engagement can include how someone sees, follows and resends content on SM for his/her audience, helping a company to earn media, instead of buying it. Based on how trustable someone is (Oeldorf-Hirsch \& DeVoss, 2019) and the content, for instance, positive or negative (Spottswood \& Wohn, 2019) and based on technology issues (Zhu, 2019), it can be moderated.

\section{Facebook as a digital marketing tool}

Social networking sites allow for interaction between consumers and the community and facilitate the "asynchronous, immediate, interactive, low-cost communications" (Miller et al., 2009). According to Kaplan and Haenlein (2010), SM, Facebook in particular, represent a vast area of opportunities for firms. Facebook has many types of pages and other ways that allow people to connect, but there are, according to Strand (2011), four main types of Facebook pages: personal pages, fan pages, official pages and community pages.

Facebook has become a significant tool in engaging with consumers and creating brand awareness (Malhotra, Kubowicz Malhotra, \& See, 2013). Approximately 2.2bn people currently have a Facebook profile according to data from 2017. According to a study conducted by Nielsen in 2012, around 53 per cent of Facebook members follow brands at least once per month, learn more about brands (65 per cent) or hear of others' experiences with brands (70 per cent) (The Nielsen Company, 2012).

Facebook (2019), with more than 2.2bn users, is the largest form of SM worldwide. It generated more than $\$ 55 \mathrm{bn}$ of revenue in 2018, it is the sixth company in the world in market value, with $\$ 22 \mathrm{bn}$ net income, it is a huge company and an important media to worldwide advertisement, and around 50 per cent of its revenue comes outside USA. Companies need to have a Facebook fan page, which must be well configured and customised (Valos, Habibi, Casidy, Driesener, \& Maplestone, 2006; Mangold \& Faulds, 2009). In 2019, in Portugal, Facebook's relevance has been seen to be high: about $6.5 \mathrm{~m}$ of people are its users ( 65 per cent of the total population) and 90 per cent of all internet users are on Facebook, the first website
Engagement on social media

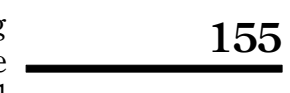


REGE 27,2

in the country. Portuguese people, in an international ranking, have taken the first place in looking for information online and 15 per cent have the habit of checking Facebook as long as they are awake (Hootsuite, 2019).

Consequently, companies invest a lot in SM platforms by creating brand fan pages on which companies publish brand posts that users can like, comment on or share, and where the company can reply to comments (De Vries, Gensler, \& Leeflang, 2012; Labrecque, 2004).

Through Facebook, companies can connect with many more people, more than through phone calls, e-mails or meetings (Luke, 2009). Moreover, costs of communication have fallen drastically with this SM, generating opportunities for companies to communicate quickly, directly and consistently with millions of customers (Mize, 2009; Palmer \& Koenig-Lewis, 2009).

For several applications, Facebook has contributed to generate more sales and opportunities, for instance on destination tourism marketing (Villamediana, Küster, \& Vila, 2019), B2B context (Zhang \& Li, 2019) and cultural experiences (Vredeveld \& Coulter, 2019).

However, researchers have highlighted risks of overuse of SM, including anxiety and FOMO (Larkin \& Fink, 2016), and even risk of socialisation and formation of social bubbles (Cardenal, Aguilar-Paredes, Galais, \& Pérez-Montoro, 2019). People are deciding to give up SM (Burtăverde, Avram, \& Vlăsceanu, 2019), and what motivates someone to engage on Facebook (Machado, Azar, Vacas de Carvalho, \& Mender, 2016) and even socialising negative content have become a topic of discussion. These criticisms include privacy issues about consumers and companies' data.

\section{The seven functional blocks of social media}

Kietzmann, Hermkens, McCarthy, and Silvestre (2011) developed a honeycomb framework that identifies seven functional building blocks of SM: identity, conversations, sharing, presence, relationships, reputation and groups. According to them, each block allows us to unpack and examine a specific facet of SM user experience and its consequences for companies. It is not necessary to include all of the building blocks in any given SM action. They are constructs that allow us to understand the different levels of SM functionality.

Identity. For Kietzmann et al. (2011), identity represents the extent to which users reveal their identities in an SM setting. On Facebook, users can define the information they share and with whom they share that information. For example, information such as name, age, gender, profession, location and also information that exposes Facebook users in certain ways. For instance, the authors explain that thoughts, feelings, likes and dislikes of users can also be shared, both consciously and unconsciously. One major implication of "identity" is privacy. Users share their identities on SM sites; however, this does not mean they do not care what happens to this information (Kietzmann et al., 2011).

Moreover, Machado et al. (2016) stated that on Facebook, trust in brands and in other users who like the same brand can influence consumers' decisions to engage online with brands. They also mentioned that according to Swani, Milne, and Brown (2013), positive word of mouth (WOM) can be comparable to "liking". When a user likes certain content, it appears on their Facebook news feed as well as on their friends' newsfeeds.

Conversations. The "conversations" block of the framework represents a level of communication on an SM platform with other users, which could be the number of regularity of postings (Kietzmann et al., 2011). According to Machado et al. (2016), on SM platforms, consumers can find out more about a certain company through the knowledge and know-how of other users. Through comments, consumers can also contribute to brand-related content (Shu \& Chuang, 2011). One major implication of the "conversations" block is "conversation velocity and the risks of starting and joining" (Kietzmann et al., 2011, p. 243).

Sharing. "Sharing" refers to the sending and receiving of content between users on the same SM platform, such as photos, comments and videos (Kietzmann et al., 2011). Machado et al. (2016) 
mentioned that besides "likes" and "comments", SM metrics should comprise the number of "shares" (Hoffman \& Fodor, 2010). By interacting with a brand on SM, consumers can feel an interpersonal social interaction (Hudson, Huang, Roth, \& Madden, 2016).

According to Kietzmann et al. (2011), the "sharing" block of the honeycomb has two implications for companies with ambition to engage in SM. First, companies need to understand "what objects of sociality their users have in common, or to identify new objects that can mediate their shared interests". Second, companies need to evaluate "the degree to which the object can or should be shared" (p. 245).

Presence. Presence refers to the ability of one user to know if other users are available. This includes knowing where other SM users are in virtual and in real life. In the virtual world, we can control this "through status lines like available or hidden" (p. 245). For example, on Facebook, users can click on a chat button to indicate if they are online and available, or do not wish to connect with other users (Kietzmann et al., 2011).

Kietzmann et al. (2011) stated that an implication of the framework building block "presence" is that "firms need to pay attention to the relative importance of user availability and user location. A firm might also want to investigate if users have a desire for selective presences, where one can be visible to some people while staying hidden to others" (p. 246). Another implication of "presence" is that it is related to other functional blocks in the honeycomb framework, such as "conversations" and "relationships". For instance, companies should recognise that "social media presence is influenced by the intimacy and immediacy of the relationship medium, and that higher levels of social presence are likely to make conversations more influential" (p. 246).

Relationships. "Relationships" refer to how people are connected on an SM platform. Machado et al. (2016) stated that in social networking sites, consumers use brands in order to create a self-identity (Schau \& Gilly, 2003), and when they "like" a brand via Facebook, they create an impression on others (Hollenbeck \& Kaikati, 2012; Wallace, Buil, \& Chernatony, 2012) and increment their social involvement (Shu \& Chuang, 2011). Facebook users can identify family members and make notes of mutual friends between users. When users are "relating" to each other on SM platforms, it means that they have a form of connection that leads them to "converse, share objects of sociality, meet up, or simply just list each other as a friend or fan". When a certain SM site or company desires to engage with its fans, it should find out how it can maintain and/or build relationships (Kietzmann et al., 2011, p. 246).

According to Hudson et al. (2016), when a company interacts with its fans by replying to comments, solving problems and inviting them to participate, fans feel a higher level of relationship quality and create a feeling of connection.

Reputation. "Reputation" refers to the ability of users to identify the standing of others (including themselves) within an SM platform. For example, Facebook users can "like" certain content and comment on it. According to Kudeshia, Sikdar and Mittal (2015), online reputation is an important element for the success of a company. An online presence allows companies to understand their customer's feelings about the brand and it could also be an opportunity to avoid any negative thoughts.

Online reputation management is very important for online community marketers (Kietzmann et al., 2011). According to Baxi, Panda, and Karani (2016), one negative comment on company SM platforms can create a negative impact on the minds of other community members. To restrict the negative impact, quick responses to every negative comment are required. Negative WOM publicity has a higher impact than positive WOM publicity.

According to Kudeshia et al. (2015), online reputation is an important element for the success of a company. An online presence allows companies to understand their customer's feelings about the brand and it could also be an opportunity to avoid any negative thoughts. 
REGE 27,2

Groups. "Groups" refer to the capacity of users to "form communities and sub-communities". When SM users "like" the same brand, they form a community (Kietzmann et al., 2011, p. 247). On Facebook, users can also form communities by organising their friends into different groups (Parsons, 2013). According to Machado et al. (2016) and Daugherty, Eastin, and Bright (2008), social interaction is very important for the creation of user-generated content, "as by creating content consumers can connect with others, experience a sense of community and feel important" (p. 171). Moreover, by interacting with a brand through SM platforms, consumers can feel an interpersonal interaction and an intimacy feeling (Hudson et al., 2016).

A fan page's success on any SM depends on consumer engagement with the brand or company. To achieve this, it is important to have good planning in the networks and the web as a whole, which should be carried out proficiently (Trainini \& Torres, 2015).

\section{Methodology}

This study is based on a qualitative and interpretative method - action research (Taba \& Noel, 1957; Thiollent, 1997; Tripp, 2005; Machin-Mastromatteo \& Tarango, 2019). This method proposes an analysis based on a cycle in which "one improves practice by systematically oscillating between taking action in the field of practice, and inquiring into it" (Tripp, 2005).

We consider the action inquiry cycle (Machin-Mastromatteo \& Tarango, 2019) in five phases. The first phase is the diagnostic phase, when the phenomena are described in the field. The second phase is the planning phase, when an intervention is created and planned. The third one is the intervention phase, when actions are made. The fourth is the observation phase, where data are collected to analyse actions' effects. The fifth is the evaluation and reflection phase, when, based on data analysis, best practices are elected.

\section{Phase 1 - diagnosis}

Alento is a Portuguese human resources (HR) services provider company. Created in 2012, it is based on the cities of Braga and Porto. Its focus relies on consulting services to companies (recruiting, selecting, training and planning services) and people looking for a job (coaching, outplacement and training services). Among its clients, youngsters and people looking for their first jobs form important segments, and B2B and B2C services are among its services (Alento, 2019).

HR companies have important relationships with both companies and candidates, in B2B and B2C contexts. Therefore, engagement can vary depending on the kind of public considered. Considering the aim of this study, we analyse the company's presence on Facebook and its publications.

\section{Phase 2 - planning}

Based on Alento's publications and their results on Facebook between January and September 2017, the changes that Alento's SM management could implement were identified. Facebook's profile was focussed on identity and profile blocks of honeycomb. To have a deeper engagement, all the seven blocks must be reflected in this activity.

So, we have come up with a list of practices to complete what is needed. Thus, this first action plan aims to define strategies that allow for correcting, improving and implementing other aspects that can help the organisation to fulfil the objectives of this study. In Table I, we can see the strategies that were implemented before and during the intervention (between September 2016 and January 2017), allocated to each building block.

Then, we proposed to create a survey to be taken by Alento Facebook fans to determine the extent to which a company should focus on some or all of the building blocks of Facebook engagement with fans previously described. At last, considering the results obtained in the 


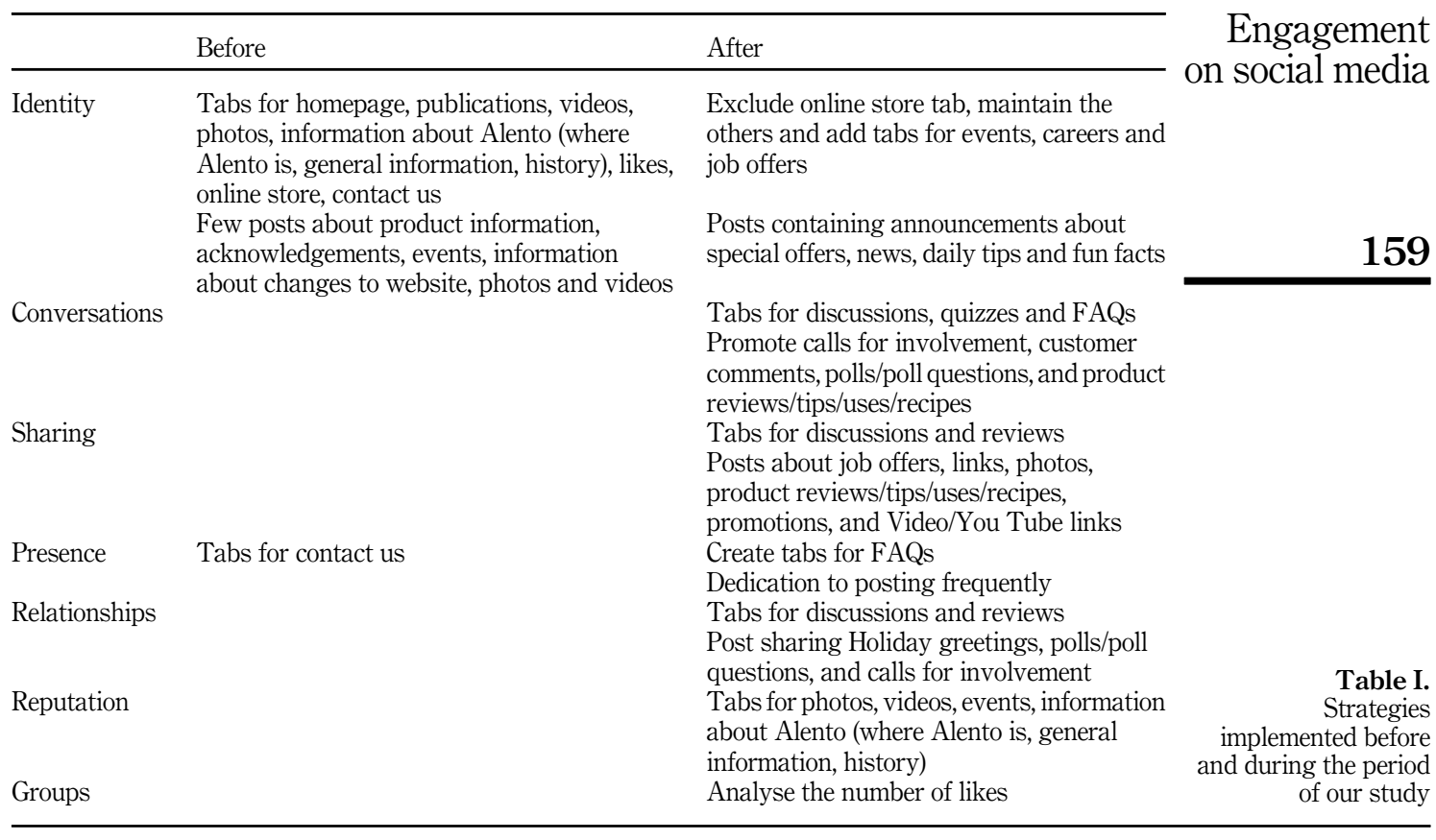

quantitative study and strategies developed during this period, we will propose some strategies that the company must implement on its Facebook page.

\section{Phase 3 - intervention}

Alento started and followed the new protocol of SM management during the given period. We proposed a greater incidence in strategies allocated to the "presence", "identity" and "reputation" building blocks to Alento. Therefore, it is recommended that a company should dedicate its time to post frequently, analysing the number of likes (to see if likes have increased or decreased) and the reviews of fans. It is also necessary to create posts containing announcements about special offers, product information, news, daily tips and fun facts.

\section{Phase 4-observation}

To analyse the impact of actions proposed in Phase 2 and implemented in Phase 3, it was needed to consider the "statistics" available on Facebook, such as the number of "followers", "interactions", "reach of publications" and "clicks on publications by type". Results can be found in Table II. By analysing these data, it is observed that Alento has increased its number of followers, interactions, views and fans who clicked on Alento's Facebook page's content. Clicks and number of fans have increased by more than 100 per cent.

Then, a survey was conducted to analyse the profile of followers and their perception about those implemented actions. Data were collected during February 2017, by accessing directly consumers on the Facebook page.

Sample. A convenience sample of 205 usable questionnaires was collected. The population of the study comprised Portuguese Facebook users who liked the Alento's Facebook Fan Page. In all, 119 of the respondents were female (58 per cent) and 86 were male ( 42 per cent). Characterising the respondents by age group, the majority of participants were concentrated in the age group "15 to 24 years" (72.7 per cent). The 25-34-age group also stood out, 
REGE

27,2

160

representing 17.1 per cent of the respondents. Regarding residence, the majority of respondents were from Porto, Braga and Lisboa, representing 47.3, 33.7 and 9.8 per cent, respectively. The majority of the respondents had a university degree (51.7 per cent), 29.3 per cent had a postgraduate or master's degree and 17.1 per cent had completed secondary education. Regarding the professions of the respondents, there was a predominance of students (57.1 per cent), followed by managers/businessman (8.8 per cent) and marketing, communication and sales professionals (6.8 per cent). Concerning the time spent on Facebook, 31.7 per cent of the respondents spent between $1 \mathrm{~h}$ and $2 \mathrm{~h}$ per day on Facebook, 30.7 per cent of them spent between 30 min and 1 h, 22 per cent spent more than 2 hon it and only 15.6 per cent used it for less than 30 min per day.

Variables and measures. The seven independent constructs (identity, conversations, sharing, presence, relationships, reputation and groups) and the dependent variable (Facebook engagement) were all measured by multiple item scales using a five-point Likert scale, with "strongly disagree" to "strongly agree" being the endpoints. The control variables (age group, residence, time spent on Facebook per day and gender) were all measured by multiple choice.

To study the "identity" building block, we adapted the scales used by Cheung and Leung (2016) and Machado et al. (2016). Regarding the "conversations" building block, we adjusted the scales used by Machado et al. (2016). To study the "sharing" building block, we adjusted the scales used by Machado et al. (2016) and Hudson et al. (2016) in their study. To analyse the "presence" building block, we created a scale on the basis of the "presence" functional building block of SM of Kietzmann et al. (2011). To investigate the "relationships" building block, we adapted the scales used by Machado et al. (2016) and Hudson et al. (2016). For the "reputation" building block, we created a scale on the basis of the "reputation" functional building block of SM of Kietzmann et al. (2011). Finally, to study the "groups" building block, we adapted the scales used by Machado et al. (2016) and Hudson et al. (2016) in their research.

Statistical procedures. One-way analysis of variance (ANOVA). We wished to discover if the age group of participants affected the seven different building blocks of SM (identity, conversations, sharing, presence, relationships, reputation and groups). One-way ANOVA can be used when there is a quantitative outcome with a categorical explanatory variable that has two or more levels.

In analysing the results, we verified that there is a statistically significant effect of the participants' age on the level of perception of importance of the block $\mathrm{F}(4,200)=0.614, p>0.05$ ), and there is a statistically significant effect of the participants' age on the conversations block $(\mathrm{F}(4,200)=3.28, p<0.05)$, the block "sharing" $(\mathrm{F}(4,200)=3.17, p<0.05)$ and the "presence" block $(\mathrm{F}(4,200)=3.75, p<0.05)$. However, there is no statistically significant effect of age on identity, relationships, reputation or the "groups" block. The Bonferroni correction post hoc tests revealed that participants aged 25-34 have a higher perception of the importance of the conversations and sharing blocks compared to participants aged 15-24 $(\phi<0.05)$.

\begin{tabular}{lcccc}
\hline & $\begin{array}{c}\text { Total followers of } \\
\text { Alento's Facebook } \\
\text { Fan Page }\end{array}$ & $\begin{array}{c}\text { Total number of fans who } \\
\text { interacted with Alento's } \\
\text { Facebook Fan Page }\end{array}$ & $\begin{array}{c}\text { Total number of fans who } \\
\text { saw any of Alento's } \\
\text { Facebook Page's content }\end{array}$ & $\begin{array}{c}\text { Link } \\
\text { clicks }\end{array}$ \\
\hline September & 3,616 & 596 & 21,869 & 138 \\
October & 3,630 & 696 & 32,959 & 285 \\
November & 3,720 & 911 & 44,704 & 263 \\
December & 3,728 & 785 & 45,714 & 313 \\
January & 3,781 & 805 & 48,526 & 340 \\
Evolution & 4.56 & 35.07 & 121.89 & 146.38 \\
$(\%)$ & & & & \\
\hline
\end{tabular}

Table II.

Evolution on engagement after five months 
We wished to analyse whether the place of residence of the participants has an effect on the seven different building blocks of SM (identity, conversations, sharing, presence, relationships, reputation and groups). The exploratory data analysis (AED) revealed that the assumption of normality (Kolmogorov-Smirnov and Shapiro-Wilk), as well as homogeneity (Levene Statistic), is guaranteed. The results of ANOVA confirm that there is a statistically significant effect of the residence of participants on the perceptions of importance of the relationships block $(\mathrm{F}(8,196)=2.09, p<0.05)$ and of the reputation block $(\mathrm{F}(8,196)=3.11, p<0.05)$. However, there is no statistically significant effect on the identity, conversations, sharing, presence and groups blocks. Post hoc tests with Bonferroni correction reveal that participants from Braga have a greater perception of the importance of the "relationships" block compared to participants living in Lisboa, and participants from Porto also have a higher perception of the importance of the "reputation" block compared to participants living in Lisboa.

We analysed whether the time participants spent on Facebook per day had an effect on the seven different building blocks of SM (identity, conversations, sharing, presence, relationships, reputation and groups).The exploratory data analysis (AED) revealed that the assumption of normality (Kolmogorov-Smirnov and Shapiro-Wilk), as well as homogeneity (Levene Statistic), is guaranteed. The ANOVA results confirm that there is a statistically significant effect of the time participants spend per day on Facebook on their perceptions of the importance of the "presence" block $(\mathrm{F}(3,201)=139.29, p<0.05)$. Post hoc tests with Bonferroni revealed that participants who spend more than $2 \mathrm{~h}$ a day on Facebook have a greater perception of the importance of the "presence" block compared to those who spend between $1 \mathrm{~h}$ and $2 \mathrm{~h}$ and between $30 \mathrm{~min}$ and $1 \mathrm{~h}$. However, there is no statistically significant effect of the identity, conversations, sharing, relationships, reputation and groups blocks.

We analysed whether the participants' gender has an effect on the seven different building blocks of SM (identity, conversations, sharing, presence, relationships, reputation and groups). The exploratory data analysis (AED) revealed that the assumption of normality (Kolmogorov-Smirnov and Shapiro-Wilk), as well as homogeneity (Levene Statistic), is guaranteed. The ANOVA results indicate that there is a statistically significant effect of the gender of the participants on the level of perception for "conversations" $(F(1,203)=5.64$, $p<0.05)$ and "relationships" $(\mathrm{F}(1,203)=7,87, p<0.05)$, and men have a higher average than women. However, there is no statistically significant effect on identity, sharing, presence, reputation and groups.

We summarised these results in Table III.

\section{Phase 5 - reflections}

Through our empirical study, we emphasise the importance of some demographic and social aspects. For example, regarding age groups, we concluded that participants aged between 25 and 34 years have a greater perception of the importance of the "conversations" block

\begin{tabular}{|c|c|c|c|c|c|}
\hline & Age & City & Gender & $\begin{array}{l}\text { Users that spent more } \\
\text { than } 2 \mathrm{~h} \text { on SM per day }\end{array}$ & \\
\hline $\begin{array}{l}\text { Identity } \\
\text { Conversations } \\
\text { Sharing } \\
\text { Presence } \\
\text { Relationships } \\
\text { Reputation } \\
\text { Groups }\end{array}$ & $\begin{array}{l}25-34>15-24 \\
25-34>15-24\end{array}$ & $\begin{array}{l}\text { Braga }>\text { Lisboa } \\
\text { Porto }>\text { Lisboa }\end{array}$ & Men>Women & Heavy users $>$ Others & $\begin{array}{l}\text { Table III. } \\
\text { Summary of user's } \\
\text { importance results }\end{array}$ \\
\hline
\end{tabular}

Engagement on social media 
REGE 27,2 compared to participants aged between 15 and 24, and in perceptions regarding the "sharing" block, participants who are 25-34-year old give more importance to this component compared to those who are 15-24-year old. Thus, when developing Facebook strategies, Alento must consider these age groups. Place of residence is another demographic factor that Alento should contemplate. Participants from Braga have a greater perception of the importance of the "relationships" block when compared to participants living in Lisboa. Also, participants from Porto have a higher perception of the importance of the "reputation" block compared to participants who live in Lisboa.

Furthermore, participants who spend more than $2 \mathrm{~h}$ a day on Facebook have a higher perception of the importance of the "presence" block compared to those who spend less time per day on Facebook. Therefore, Alento should consider this when managing its Facebook page. Finally, the company should also consider the gender of respondents when developing Facebook strategies for the "relationships" and "conversations" blocks.

\section{Final thoughts}

The main objective of this research was to provide a solution for a problem raised by Alento, which was to understand how the company should engage with its official Facebook page.

This investigation explored the seven functional building blocks of SM engagement proposed by Kietzmann et al. (2011): identity, conversations, sharing, presence, relationships, reputation and groups. We tried to find out which of the functional blocks of SM engagement were more important for Alento's Facebook Fan Page to understand how the company should engage with it. Other variables were also studied, such as age, residence, time spent on Facebook per day and gender of Alento Facebook fans, to understand their perception of the importance of functional building blocks of Alento's Facebook engagement.

Consequently, we surveyed among 205 Alento Facebook fans, to explore Alento's Facebook fans' habits when using Facebook, to understand the extent to which Alento should focus on some or all of the functional building blocks of Facebook engagement. Results indicated that, contrary to what was expected, the most important functional building blocks for Alento's Facebook Fan Page's engagement were "presence", "identity" and "reputation". Furthermore, there are some factors that Alento should consider when engaging with its Facebook page, such as the 25-34-age group when developing strategies to increase conversations and sharing. Regarding place of residence, Alento must consider participants from Braga and Porto when developing strategies for relationships and reputation, respectively. Concerning time spent on Facebook per day, participants who spent more than $2 \mathrm{~h}$ a day on Facebook had a greater perception of the importance of the presence block compared to those who spent less time on Facebook. Finally, the company should also consider gender when developing strategies for the relationships and conversations functional building blocks of Alento's Facebook engagement.

In parallel, we analysed some Alento Facebook strategies developed during the period of five months, through statistics available on Facebook. Our results indicated that there was an increase in Alento's number of followers, interactions, views and fans who clicked on Alento's Facebook page's content. Considering the results obtained in our empirical study, we concluded that Alento should focus on the presence, identity and reputation functional building blocks of Facebook engagement. Additionally, Alento must implement Facebook strategies developed between September and January that focussed on these blocks, considering some demographic and social factors.

This study is based on a case study, and its relevance consists of a special case of different kinds of engagement (B2B and B2C, simultaneous), a longer observation based on real data gathered by different means and the direct intervention on the field. This can be relevant to other service companies to get similar results on their own SM. 
Facebook is a huge media company and can bring opportunities in terms of earned media and engagement to companies, including the small ones. In Portugal, there is still a total dominance of Facebook, but in the future, other SM, such as Instagram, can capture the audience and be a threat to Facebook or an opportunity to earn more media.

\section{Limitations and suggestions for further research}

There were also some limitations related to the sample, since we only obtained 205 responses. Therefore, the second suggestion for future investigations would be to conduct survey among a larger number of people. This study just considered five months after changing procedures. A longer range of time could produce different results. Other studies can focus on other SM, such as Instagram or LinkedIn, including how integrated these platforms are to companies' website. Moreover, criticisms about SM such as privacy and data security issues could be studied as moderators of engagement.

\section{References}

Alento (2019). Conheça a empresa. Available from: www.alento.pt/empresa (accessed 19 January 2019).

Baxi, B., Panda, R., \& Karani, A. (2016). Community marketing: An effective marketing strategy. Romanian Journal of Marketing, 3(3), 2-11.

Boyd, D. M., \& Ellison, N. B. (2007). Social network sites: definition, history and scholarship. Journal of Computer-Mediated Communication, 13(1), 210-230.

Buhalis, D., \& Law, R. (2008). Progress in information technology and tourism management: 20 years on and 10 years after the internet - the state of e-Tourism research. Tourism Management, 29(4), 609-623.

Burtăverde, V., Avram, E., \& Vlăsceanu, S. (2019). Not using social media. A socioanalytic perspective. Computers in Human Behavior, 101. Available from: https://doi.org/10.1016/j.chb.2019.07.030

Cardenal, A. S., Aguilar-Paredes, C., Galais, C., \& Pérez-Montoro, M. (2019). Digital technologies and selective exposure: How choice and filter bubbles shape news media exposure. International Journal of Press/Politics. Available from: https://doi.org/10.1177/1940161219862988

Cheung, F., \& Leung, W. (2016). Facebook users' habits in getting commercial information: A study on Hong Kong students. Journal of Economics, Management, and Financial Markets, 11(3), 56-71.

Daugherty, T., Eastin, M., \& Bright, L. (2008). Exploring consumer motivations for creating usergenerated content. Journal of Interactive Advertising, 8(2), 16-25.

De Vries, L., Gensler, S., \& Leeflang, P. (2012). Popularity of brand posts on brand fan pages: An investigation of the effects of social media marketing. Journal of Interactive Marketing, 26(2), 83-91.

Dhir, A., \& Torsheim, T. (2016). Age and gender differences in photo tagging gratifications. Journal of computers in Human Behavior, 63(October), 630-638.

Diba, H., Vella, J., \& Abratt, R. (2019). Social media influence on the B2B buying process. Journal of Business \& Industrial Marketing, 3. Available from: https://doi.org/10.1108/JBIM-12-2018-0403

Erragcha, N., \& Romdhane, R. (2014). Social networks as marketing tools. Journal of Internet Banking and Commerce, 19(1), 1-12.

Facebook (2019). Facebook reports second quarter 2019 results. Available from: statista.com (accessed 19 January 2019).

Hargittai, E. (2007). Whose space? Differences among users and non-users of social network sites. Journal of Computer-Mediated Communication, 13(1), 276-297.

Hoffman, D., \& Fodor, M. (2010). Can you measure the ROI of your social media marketing?. MIT Sloan Management Review, 52(1), 55-61.

Hollebeek, L. (2011). Exploring customer brand engagement: Definition and themes. Journal of Strategic Management, 11(7), 555-573. 
REGE 27,2

Hollebeek, L., Andreassen, W. T., Smith, D., Grönquist, D., Karahasanovic, A., \& Márquez, A. (2018). Epilogue - service innovation actor engagement: an integrative model. Journal of Services Marketing, 32(1), 95-100. Available from: https://doi.org/10.1108/JSM-11-2017-0390

Hollenbeck, C., \& Kaikati, A. (2012). Consumers' use of brands to reflect their actual and ideal selves on Facebook. International Journal of Research in Marketing, 29(4), 395-405.

Hootsuite (2019). Portugal's digital 2019. Available from: https://wearesocial.com/blog/2019/01/digital2019-global-internet-use-accelerates (accessed 19 January 2019).

Hudson, S., Huang, L., Roth, M., \& Madden, T. (2016). The influence of social media interactions on consumer-brand relationships: A three-country study of brand perceptions and marketing behaviors. International Journal of Research in Marketing, 33(1), 27-41.

Joiner, R., Gavin, J., Brosnan, M., Cromby, J., Gregory, H., Guiller, J., Maras, P., \& Moon, A. (2012). Gender, internet experience, internet identification and internet anxiety: a ten year follow-up. Journal of Cyberpsychology, Behavior, and Social Networking, 15(7), 370-372.

Kaplan, A. M., \& Haenlein, M. (2010). Users of the world, unite! The challenges and opportunities of social media. Business Horizons, 53(1), 59-68.

Kesgin, M., \& Murthy, R. S. (2019). Consumer engagement: The role of social currency in online reviews. Service Industries Journal, 39(7-8), 609-636. Available from: https://doi.org/10.1080/ 02642069.2018.1553237

Kietzmann, J. H., Hermkens, K., McCarthy, I., \& Silvestre, B. (2011). Social media? Get serious! Understanding the functional building blocks of social media. Business Horizons, 54(3), 241-251.

Kudeshia, C., Sikdar, P., \& Mittal, A. (2015). Spreading love through fan page liking: a perspective on small scale entrepreneurs. Computers in Human Behavior, 54(January), 257-270.

Labrecque, I. (2004). Fostering consumer-brand relationships in social media environments: The role of parasocial interactions. Journal of Interactive Marketing, 28(2), 134-148.

Larkin, B., \& Fink, J. (2016). Fantasy sport, FoMO, and traditional fandom: How second-screen use of social media allows fans to accommodate multiple identities. Journal of Sport Management, 30(6), 643-655.

Luke, K. (2009). Marketing the new-fashioned way: connect with your target market through social networking sites. Journal of Financial Planning, November-December, 18-19.

Machado, J., Azar, S., Vacas de Carvalho, L., \& Mender, A. (2016). Motivations to interact with brands on Facebook - towards a typology of consumer-brand interactions. Journal of Brand Management, 23(2), 153-178.

Machin-Mastromatteo, J., \& Tarango, J. (2019), "Participatory action research", In R. Hobbs \& P. Mihailidis (Eds), The international encyclopedia of media literacy, (1-8). New York, NY: John Wiley \& Sons. Available from: https://doi.org/10.1002/9781118978238.iem10178 (accessed 19 January 2019).

Madden, M., Lenhart, A., \& Duggan, M. (2013). Teens and technology 2013. Pew Research Center's Internet \& American Life Project, Washington, DC.

Maecker, O., Barrot, C., \& Becker, J. U. (2016). The effect of social media interactions on customer relationship management. Journal of Business Research, 9(1), 133-155.

Malhotra, A., Kubowicz Malhotra, C., \& See, A. (2013). How to create brand engagement on Facebook. MIT Sloan Management Review, 54(2), 18-20.

Mangold, W. G., \& Faulds, D. (2009). Social media: the new hybrid element of the promotion mix. Business Horizons, 52(4), 357-365.

Mazman, S., \& Usluel, Y. (2010). Modeling educational usage of Facebook. Journal of Computers \& Education, 55(2), 444-453.

Miller, K. D., Fabian, F., \& Lin, S. J. (2009). Strategies for online communities. Strategic Management Journal, 30(3), 305-322. 
Mize, S. R. (2009). Social network benefits. Available from: http://ezinearticles.com/?Social-NetworkBenefits\&id $=464645$ (accessed 10 February).

Moriuchi, E. (2019). Okay, Google!: An empirical study on voice assistants on consumer engagement and loyalty. Psychology and Marketing, 36(5), 489-501. Available from: https://doi.org/10.1002/ mar.21192

Mutinga, D. G., Moorman, M., \& Smit, E. G. (2011). Introducing COBRAs: Exploring motivations for brand-related social media use. International Journal of Advertising, 30(1), 13-46.

Muscanell, N. L., \& Guadagno, R. E. (2012). Make new friends or keep the old: Gender and on social media personality differences in social networking use. Journal of Computers in Human Behavior, 28(1), 107-112.

Oeldorf-Hirsch, A., \& DeVoss, C. L. (2019). Who posted that story? Processing layered sources in Facebook news posts. Journalism and Mass Communication Quarterly. Available from: https:// doi.org/10.1177/1077699019857673

Ofcom (2008). Social networking: a quantitative and qualitative research report into attitudes, behaviors and use. Available from: http://news.bbc.co.uk/2/shared/bsp/hi/pdfs/02_04_08_ ofcom.pdf (accessed 19 January 2019).

Palmer, A., \& Koenig-Lewis, N. (2009). An experimental social network-based approach to direct marketing. Direct Marketing: An International Journal, 3(3), 162-176.

Parsons, A. (2013). Using social media to reach consumers: A content analysis of official Facebook pages. Academy of Marketing Studies Journal, 17(2), 27-36.

Pfeil, U., Arjan, R., \& Zaphiris, P. (2009). Age differences in online social networking: A study of user profiles and the social capital divide among teenagers and older users in MySpace. Journal of Computers in Human Behavior, 25(3), 643-654.

Ramsaran-Fowdar, R., \& Fowdar, S. (2013). The implications of Facebook marketing organizations. Contemporary Management Research, 9(1), 73-84.

Sánchez, R., Cortijo, V., \& Javed, U. (2014). Students' perceptions of Facebook for academic purposes. Journal of Computers \& Education, 70(January), 138-149.

Schau, H., \& Gilly, M. (2003). We are what we post? Self-presentation in a personal web space. Journal of Consumer Research, 30(3), 385-404.

Shu, W., \& Chuang, Y. H. (2011). The perceived benefits of six-degree-separation social networks. Internet Research, 21(1), 26-45.

Silva, S. C., Bradley, F., \& Sousa, C. M. (2012). Empirical test of the trust-performance link in international alliances context. International Business Review, 21(2), 293-306.

Spottswood, E., \& Wohn, D. Y. (2019). Beyond the like: How people respond to negative posts on Facebook. Journal of Broadcasting and Electronic Media, 63(2), 250-267. Available from: https:// doi.org/10.1080/08838151.2019.1622936

Strand, J. (2011). Facebook: Trademarks, fan pages, and community pages. Intellectual Property \& Technology Law Journal, 23(1), 10-13.

Swani, K., Milne, G., \& Brown, B. (2013). Spreading the word through likes on Facebook: Evaluating the message strategy effectiveness of Fortune 500 companies. Journal of Research in Interactive Marketing, 7(4), 269-294.

Swani, K., Milne, G. R., Brown, B. P., Assaf, A. G., \& Donthu, N. (2017). What messages to post? Evaluating the popularity of social media communications in business versus consumer markets. Industrial Marketing Management, 62(April), 77-87.

Taba, H., \& Noel, E. (1957), Action research: a case study, Association for Supervision and Curriculum Development (NEA), Washington, DC.

Taiminen, H., \& Karjaluoto, H. (2015). The usage of digital marketing channels in SMEs. Journal of Small Business and Enterprise Development, 22(4), 633-651. 
REGE 27,2

The Nielsen Company (2012). State of the media: The social media report. Available from: https:// womseo.com/wp-content/uploads/2012/12/The-Social-Media-Marketing-Report-2012.pdf (accessed 19 January 2019).

Thiollent, M. (1997), Pesquisa-ação nas organizações, Ed. Atlas, São Paulo.

Trainini, M., \& Torres, J. (2015). Mídias Sociais como ferramentas de estratégias de Marketing. Revista Ciência e Conhecimento, 9(1), 23-40.

Tripp, M. (2005). Action research - a methodological introduction. Educação e pesquisa, SeptemberDecember, 31(3), 443-466.

Tsimonis, G., \& Dimitriadis, S. (2014). Brand strategies in social media. Marketing Intelligence \& Planning, 32(3), 328-344.

Valos, M. J., Habibi, F. H., Casidy, R., Driesener, C. B., \& Maplestone, V. L. (2006). Exploring the integration of social media within integrated marketing communication frameworks. Marketing Intelligence \& Planning, 34(1), 19-40.

Villamediana, J., Küster, I., \& Vila, N. (2019). Destination engagement on Facebook: Time and seasonality. Annals of Tourism Research, 79. Available from: 79https://doi.org/10.1016/j.annals. 2019.102747

Vredeveld, A. J., \& Coulter, R. A. (2019). Cultural experiential goal pursuit, cultural brand engagement, and culturally authentic experiences: Sojourners in America. Journal of the Academy of Marketing Science, 47. Available from: https://doi.org/10.1007/s11747-018-0620-7

Wallace, E., Buil, I., \& Chernatony, L. (2012). Facebook 'friendship' and brand advocacy. Journal of Brand Management, 20(2), 128-146.

Weiser, E. (2000). Gender differences in Internet use patterns and Internet application preferences: A two-sample comparison. Journal of CyberPsychology \& Behavior, 3(2), 167-178.

Yuan, Y. (2011). A survey study on uses and gratification of social networking sites in China. Master of Science, Ohio University, Athens.

Zhang, C., \& Li, Y. (2019). How social media usage influences B2B customer loyalty: Roles of trust and purchase risk. Journal of Business \& Industrial Marketing, 34(7).

Zhu, Y. (2019). Social media engagement and Chinese international student recruitment: Understanding how UK HEIs use Weibo and WeChat. Journal of Marketing for Higher Education, 29(2), 1-18.

\section{Further reading}

Barnes, N. G. (2010). Tweeting and blogging to the top. Marketing Research, 22(1), 8-13.

Bruhn, M., Schoenmueller, V., \& Schäfer, D. B. (2012). Are social media replacing traditional media in terms of brand equity creation?. Management Research Review, 35(9), 770-790.

Casteleyn, J., Mottart, A., \& Rutten, K. (2009). How to use Facebook in your market research. International Journal of Market Research, 51(4), 439-447.

Doyle, S. (2007). The role of social networks in marketing. Journal of Database Marketing \& Customer Strategy Management, 15(1), 60-64.

HBR (2009). Six social media trends for 2010. Available from: http://blogs.hbr.org/cs/2009/11/six_ social_media_trends.html (accessed 19 January 2019).

Karakaya, F., \& Barnes, N. G. (2010). Impact of online reviews of customer care experience on brand or company selection. Journal of Consumer Marketing, 27(5), 447-457.

Lacka, E., \& Chong, A. (2016). Usability perspective on social media sites' adoption in the B2B context. Industrial Marketing Management, 54(April), 80-91.

Lapointe, P. (2012). Measuring Facebook's impact on marketing. Journal of Advertising Research, 52(3).

McCarthy, I., Lawrence, T., Wixted, B., \& Gordon, B. (2010). A multidimensional conceptualization of environmental velocity. Journal of the Academy Management Review, 35(4), 604-626. 
Moss, G., Kennedy, H., Stylianos, M., \& Birchall, C. (2015). Knowing your publics: The use of social media analytics in local government. The International Journal of Government \& Democracy in the Information Age, 20(4), 287-298.

Murdough, C. (2009). Social media measurement: It's not impossible. Journal of Interactive Advertising, 10(1), 94-99.

Nair, M. (2011). Understanding and measuring the value of social media. The Journal of Corporate Accounting \& Finance, 22(3), 45-51.

Shannon, R., Stabeler, M., Quigley, A., \& Nixon, P. (2009). Profiling and targeting opportunities in pervasive advertising. 1st Workshop on Pervasive Advertising, Pervasive 1, Nara.

Smith, A. N., Fischer, E., \& Yongjian, C. (2012). How does brand-related user-generated content differ across YouTube, Facebook, and Twitter?. Journal of Interactive Marketing, 26(2), 102-113.

Smith, K.T. (2011). Digital marketing strategies that millennials find appealing, motivating, or just annoying. Journal of Strategic Marketing, 19(6), 489-499.

Treadway, C., \& Smith, M. (2010), Facebook marketing: an hour a day, Indianopolis: Wiley Publishing.

Wright, E., Khanfar, N. M., Harrington, C., \& Kizer, L. E. (2010). The lasting effects of social media trends on advertising. Journal of Business \& Economics Research, 8(11), 73-80.

\section{Corresponding author}

Wilian Feitosa can be contacted at: wrfeitosa@hotmail.com

For instructions on how to order reprints of this article, please visit our website:

www.emeraldgrouppublishing.com/licensing/reprints.htm

Or contact us for further details: permissions@emeraldinsight.com 